\title{
NOTE ON THE COVER ILLUSTRATION
}

The jacket illustration is based on a head, No. 581 in the Roman Collection of the National Archaeological Museum, Athens, Greece. The type is of a Late Antique philosopher with the characteristic outward and upward stare. The forehead is trisected exactly at $1.5 \mathrm{~cm}$ intervals from the hairline to the beginning of the nose, probably indicating the three main Neo-Platonic metaphysical levels. Made of sparkling white marble, the head measures $31.8 \mathrm{~cm}$ (12.5 inches) high, $13 \mathrm{~cm}$ wide, and $23.3 \mathrm{~cm}$ deep. Two-fifths is missing. I first inspected the head in 1980. The help of A. Stauridê and M. Oikonomidou is gratefully acknowledged. In 1990 I examined it in more detail. I thank Mrs Rômiopoulou and O. Tzachou-Alexandrê for their generous help, the photographs and publication permission.

The head was found in the south side of the Acropolis, in the Serpentzé wall, in 1876-7. This was the locality of Proclus' School (V. Procli, 29): 'in the neighbourhood of the Asclepieion temple which Sophocles made famous, and of the temple to Dionysius close to the Theatre'. Gerhart Rodenwalt published the head in a collection of late antique busts, many of them of philosophers (Griechische Porträts aus dem Ausgang der Antike (Berlin, 1919), p. 4, pl. III (n. 2)), and speculated that it might be that of Proclus. More recent research has suggested an earlier Neo-Platonist, Iamblichus (H. P. L'Orange, 'Some remarks on late Greek portraiture, especially the Iamblichos type', Acta ad Archeologiam et Artium Historiam Pertinentia 6 (1975), pp. 59-63), or perhaps Porphyry (P. Kalligas, Porphyry on the Life of Plotinus (Athens, 1991), frontispiece and appendix 3). See also E. Voutiras, 'Ein wiedergewonnenes attisches Porträt der Spätantike', Mitteilungen des Deutschen Archäologischen Instituts (Athen), 96 (1981), pp. 201-8 and A. Ntatsoulê-Stauridê, Roman Portraits in the National Archaeological Museum in Athens (in Greek) (Athens, 1985).

According to his biographer, 'Proclus was very attractive to see; for not only had he a symmetry in appearance but also the beauty of his soul bloomed on his body and, like a living light, shone wonderfully in a manner which is hard to put into words. He was so elegant to behold that none of the painters was able to capture completely his likeness: although their works were excellent, they all fell very short in the imitation of the true form' (V. Procli, 3). 


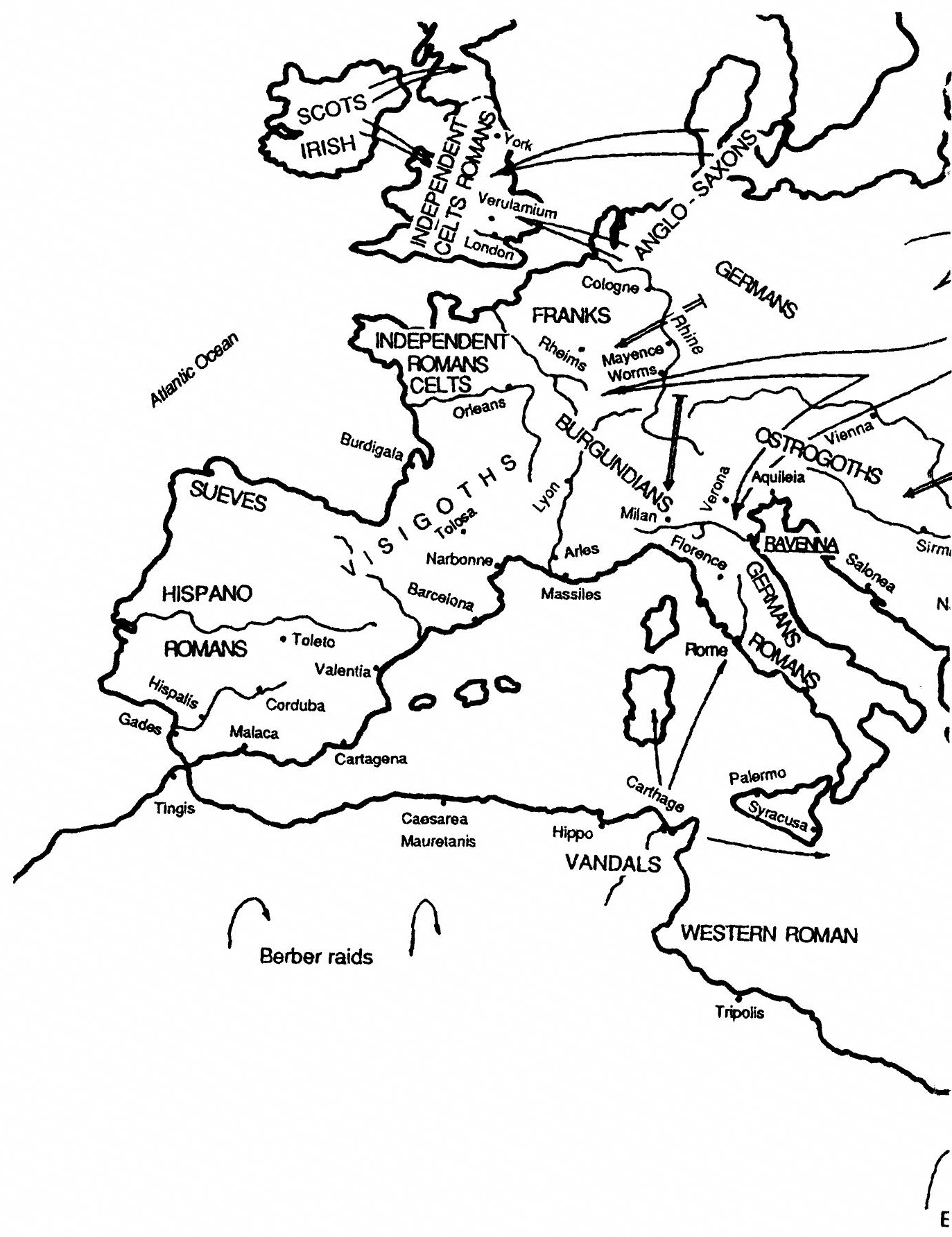

Map: Proclus' world, fifth century AD 


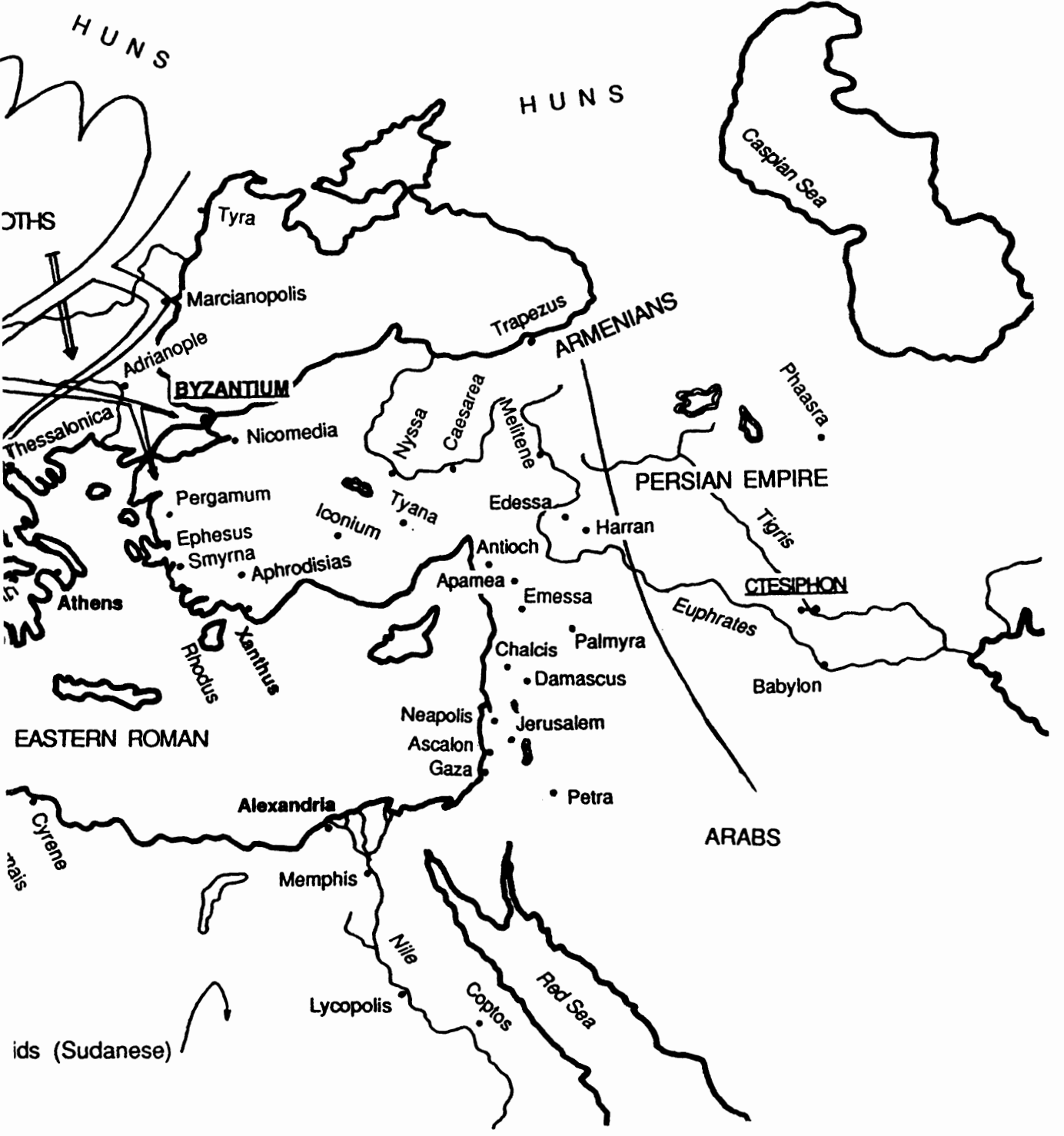


